\title{
TANGGUNG JAWAB NEGARA TERHADAP PERLINDUNGAN PEJABAT DIPLOMATIK MENURUT KONVENSI WINA 1961 (CONTOH KASUS PENYERANGAN DUTA BESAR RUSIA DI TURKI)
}

\author{
Yonathan Yogy \\ (Mahasiswa Program S1 Fakultas Hukum Universitas Tarumanagara) \\ (E-mail: yonathan.yogy@gmail.com)
}

Ida Kurnia

(Corresponding Author)

(Dosen Hukum Internasional Fakultas Hukum Universitas Tarumanagara, Meraih Sarjana Hukum dari Fakultas Hukum Universitas Diponogoro, Magister Hukum dari Fakultas Hukum Universitas Tarumanagara, Doktor Hukum dari Fakultas Hukum Universitas Gadjah Mada)

(E-mail: idah@fh.untar.ac.id)

\begin{abstract}
The establishment of diplomatic relations aims to strengthen a relationships between state. The establishment of diplomatic relations is based on mutual consent between two states. After consent has been reached, each state can dispatch members of the mission. The function of a member of the missions is to represent the sending state, to protect the interests of the sending state and its nationals, to negotiate, Ascertaining by all lawful means conditions and developments in the receiving State, and to promote friendly relations between the sending country and the receiving country. The Vienna Convention 1961 on diplomatic relations provides immunity and privilege to members of the missions in carrying out diplomatic functions. Such immunity and privilege are granted not for personal gain, it is provided to facilitate members of the missions in performing diplomatic functions. One of the forms of immunity is Inviolability. Inviolability of members of the missions is regulated by Article 29 of Vienna Convention 1961. Article 29 stated that the receiving state shall take appropriate measures to prevent any attack on members of the missions. But if the receiving state fails to protect the members of the missions, is there any legal consequence and state's responsibility?. The author is interested to raise the issue into a thesis.
\end{abstract}

Keywords: Missions, inviolability, state responsibility. 


\section{PENDAHULUAN}

\section{A. Latar Belakang}

Hubungan antar negara di era globalisasi tidak dapat hindari, karena negara membutuhkan negara lain untuk memenuhi kebutuhannya dan menjalin kerjasama di bidang tertentu sesuai dengan kepentingan masing-masing negara. Hubungan antar negara diharapkan saling menguntungkan semua pihak yang terlibat dalam hubungan tersebut.

Hubungan antar negara dapat dilakukan dengan berbagai cara, salah satunya dengan membuka hubungan diplomatik. Diplomasi diartikan sebagai : ${ }^{1)}$

The conduct by government officials of negotiations and other relations between nations; the art of science of counducting such negotiations; skill in managing negotiations, handling of people so that there is little or no ill-will act.

Dari definisi tersebut dapat diketahui diplomasi adalah tindakan oleh pejabat pemerintah tentang perundingan dan hubungan lain antar negara, ilmu pengetahuan tentang negosiasi, keterampilan mengelola negosiasi, penanganan individu sehingga tidak ada tindakan buruk yang dilakukan.

Jika suatu negara telah menyetujui pembukaan hubungan diplomatik dengan negara lain melalui suatu instrumen atas dasar asas timbal balik dan asas saling menyetujui, negara-negara tersebut sudah harus memikirkan pembukaan suatu perwakilan diplomatik dan penyusunan keanggotaan perwakilan tersebut baik dalam tingkatanya maupun jumlah anggota staf perwakilan yang telah disetujui bersama atas dasar kewajaran dan kepantasan. ${ }^{2)}$

Fungsi perwakilan diplomatik terdapat dalam Pasal 3 Konvensi Wina 1961 tentang Perwakilan Diplomatik, fungsi tersebut adalah merepresentasikan negara pengirim, melindungi kepentingan negara pengirim dan warga negaranya, melakukan negosiasi, membuat laporan keadaan dan perkembangan negara penerima serta meningkatkan hubungan kedua negara dalam bidang ekonomi,

${ }^{1)}$ Sumaryo Suryokusumo, Hukum Diplomatik Dan Konsuler Jilid I, (Jakarta: Tatanusa,2013), hal.3.

\footnotetext{
${ }^{2)}$ Ibid. hal.53.
} 
kultur dan sains. Dalam melaksanakan fungsinya, perwakilan diplomatik memiliki kekebalan dan keistimewaan diplomatik yang diatur Konvensi Wina 1961.

Kekebalan tersebut meliputi tidak diganggu gugatnya para pejabat diplomatik. ${ }^{3)}$ Menurut Pasal 29 Konvensi Wina 1961 tidak dapat diganggu gugatnya pejabat diplomatik adalah ia tidak boleh ditangkap dan dikenakan penahanan, negara penerima harus memperlakukanya dengan penuh hormat dan harus mengambil langkah-langkah yang layak untuk mencegah serangan atas dirinya, kemerdekaan dan martabatnya. Mengambil langkah-langkah yang layak untuk mencegah serangan atas dirinya dapat diartikan bahwa negara peserta Konvensi Wina 1961 memiliki kewajiban untuk mencegah serta melindungi pejabat diplomatik yang berada di wilayahnya dari berbagai serangan .

Pada praktiknya di berbagai negara banyak insiden penyerangan yang ditujukan terhadap pejabat diplomatik. Hasil dari insiden tersebut menyebabkan luka bahkan kematian terhadap pejabat diplomatik. Salah satu insiden penyerangan tersebut adalah penyerangan Duta Besar Rusia di Ankara, Turki, yang menewaskan Duta Besar Senior Rusia.

Kegagalan suatu negara dalam melindungi pejabat diplomatik merupakan suatu pelanggaran terhadap Pasal 29 Konvensi Wina 1961, sehingga menimbulkan konsekuensi internasional, tanggung jawab bagi negara pelanggar konvensi dan membahayakan hubungan yang dijalin dengan negara bersangkutan. Tanggung jawab negara dapat timbul akibat adanya suatu kewajiban hukum internasional yang berlaku antara dua negara tertentu, adanya suatu perbuatan atau kelalaian yang melanggar kewajiban hukum internasional tersebut melahirkan tanggung jawab negara, serta adanya kerusakan atau kerugian sebagai akibat adanya tindakan yang melanggar hukum atau kelalaian. ${ }^{4)}$

\footnotetext{
3) Ibid., hal.147.

4) Yudha Bhakti Ardhiwisastra, Hukum Internasional Bunga Rampai, (Bandung: PT Alumni, 2003), hal. 255.
} 
Tanggung jawab negara tersebut diatur secara umum dalam Draft State Responsibility for Internationally Wrongful Acts 2001, dalam Pasal 1 disebutkan bahwa setiap pelanggaran internasional yang dilakukan suatu negara dapat menimbulkan tanggung jawab negara. Dalam Draft tersebut Pasal 42 mengatur mengenai hak bagi setiap negara yang merasa dirugikan akibat tindakan atau kelalaian negara lain dapat meminta pertanggungjawaban negara tersebut. Sehingga tindakan yang merugikan tersebut menimbulkan konsekuensi berupa pertanggungjawaban.

Contoh kasus yang akan diambil penulis adalah penembakan Duta Besar Rusia senior bernama Andrei Karlov di Ankara Turki pada 19 Desember 2016. Penembakan tersebut terjadi saat Andrei Karlov memberikan pidato di sebuah acara seni yang disponsori pemerintah Rusia, bertempat di galeri seni Ankara. Pelaku penembakan tersebut adalah mantan polisi Turki bernama Mevlut Mert Altintas. Sampai saat ini belum diketahui bagaimana pelaku memasuki wilayah personel keamanan yang dijaga ketat. Tidak lama setelah penembakan terhadap korban, pelaku ditembak mati oleh pasukan keamanan Turki. Diketahui penembakan tersebut dilakukan oleh pelaku karena tidak terima dengan intervensi Rusia di Suriah. Dari insiden tersebut Duta Besar Rusia meninggal di rumah sakit saat diberikan perawatan. Dapat diketahui dari peristiwa di atas, Duta Besar Rusia sedang melaksanakan fungsi diplomatik dalam acara tersebut, sehingga berhak atas imunitas perlindungan dari negara penerima

Isi dari Konvensi Wina 1961 tidak mengatur secara tegas sanksi atau dampak atas pelanggaran isi konvensinya, maka penulis tergerak untuk meneliti mengenai penyelesaian dan tanggung jawab yang dapat diambil bagi negara pelanggar Konvensi Wina 1961 berdasarkan Hukum Internasional dengan contoh kasus penyerangan Duta Besar Rusia .

Berdasarkan pada latar belakang, penulis tertarik untuk melakukan penelitian dengan judul "Tanggung Jawab Negara Terhadap Perlindungan Pejabat 
Diplomatik Menurut Konvensi Wina 1961 (Contoh Kasus Penyerangan Duta Besar Rusia Di Turki)."

\section{B. Permasalahan}

Dalam penulisan jurnal ini yang menjadi pokok permasalahan adalah Bagaimana tanggungjawab Turki terhadap tewasnya duta besar Rusia di Ankara Turki berdasarkan Hukum Internasional?

\section{Metode Penelitian}

Teknik pengumpulan data yang digunakan penulis dalam penelitian ini adalah dengan studi kepustakaan yang dilakukan melalui pengumpulan data sekunder, dan data tersebut diperoleh dari bahan-bahan pustaka seperti bukubuku dan dokumen-dokumen tertulis lainnya. Adapun data-data sekunder tersebut terdiri atas:

1. Bahan Hukum Primer

2. Bahan Hukum Sekunder

3. Bahan Hukum Tersier

\section{PEMBAHASAN}

\section{A. Kasus Posisi}

Berikut adalah kasus posisi dari penembakan Duta Besar Rusia di Ankara, Turki: ${ }^{5)}$

Juru bicara Kementerian LN Rusia Maria Zakharova mengukuhkan Andrei Karlov tewas karena luka-luka yang dideritanya, "Akibat serangan hari ini di Ankara, duta besar Rusia untuk Turki, Andrei Karlov meninggal akibat lukaluka yang dideritanya" kata Zakharova. "Kami menganggap ini sebagai tindakan teroris."

Penembakan itu terjadi ketika Karlov mengadiri pameran foto berjudul "Rusia dalam pandangan Turki" yang disponsori kedutaan Rusia. AP

\footnotetext{
5) Anonim, "Dubes Rusia untuk Turki Tewas Ditembak di Pameran Foto" https://www.voaindonesia.com/a/dubes-rusia-untuk-turki-tewas-ditembak-di-pameranfoto/3642291.html, diakses pada 4 Juni 2018.
} 
mengatakan salah seorang photograpernya berada di lokasi kejadian dan melaporkan seorang laki-laki mengenakan jas dan dasi meneriakkan "Allahu Akbar" dan melepaskan sekurangnya delapan tembakan. "Jangan lupakan Aleppo, Jangan lupakan Suriah" ia kemudian berteriak dalam bahasa Turki. "Mundur-mundur. Hanya kematian yang mengeluarkan saya dari sini. Siapapun yang berperan dalam penumpasan ini akan mati satu persatu."

Seorang saksi mata mengatakan kepada VOA bahwa pengunjung melewati pintu pendeteksi metal untuk masuk ke tempat pameran itu, tapi tampaknya tidak ada tambahan keamanan terkait kehadiran duta besar Rusia itu. "Kami menjatuhkan diri ke lantai mendengar suara tembakan itu," kata reporter TV Haberturk kepada VOA. "Saya melihat senjata diarahkan ke atap dan saya melihat duta besar itu jatuh."

Bakir mengatakan ia mendengar 20-30 tembakan dan ia bersama yang lainnya melarikan diri dari lokasi penembakan itu. Kantor berita Turki NTV melaporkan polisi kemudian menembak dan menewaskan laki-laki bersenjata itu. Laporan-laporan awal mengatakan penyerang mungkin polisi yang sudah tidak bertugas. "Penyerang adalah seorang polisi," kata walikota Ankara Melih Gokcek dalam pesan Twitter.Kantor berita Rusia RIA mengatakan keamanan di sekitar kedutaan Rusia di Ankara telah ditingkatkan setelah penembakan itu.

Setelah insiden tewasnya Duta Besar Rusia di Ankara, Turki, PBB dalam situs webnya menyatakan sebagai berikut: ${ }^{6)}$

Sangat mengutuk pembunuhan hari ini Duta Besar Rusia untuk Turki Andrey Karlov di Ankara, Sekretaris Jenderal Ban Ki-moon dan Dewan Keamanan PBB menekankan bahwa tidak ada pembenaran untuk menargetkan personil diplomatik dan warga sipil.

\footnotetext{
6) Anonim,'UN Condemns Assasination of Russian Ambassador to Turkey", https://news.un.org/en/story/2016/12/548152-un-condemns-assassination-russian-ambassador-turkey, diakses pada 4 Juni 2018.
} 
"Sekretaris Jenderal terkejut oleh tindakan teror yang tidak masuk akal ini," menurut pernyataan yang dikeluarkan oleh juru bicara Ban, yang menambahkan bahwa ia juga menyatakan belasungkawa terdalamnya kepada keluarga Duta Besar Karlov dan kepada Pemerintah dan rakyat Rusia. .

Ban menekankan bahwa tidak ada pembenaran untuk penargetan personil diplomatik dan warga sipil, dan menurut pernyataan itu, dia "mengikuti situasi yang berlangsung dengan cermat" dan berharap orang lain yang dilaporkan terluka dalam serangan itu dapat pulih.

Dalam sebuah pernyataan terpisah, Dewan Keamanan juga mengutuk serangan teroris mematikan dan menyatakan belasungkawa mendalam mereka kepada keluarga Duta Besar dan Pemerintah Rusia.

Mengulangi kebutuhan untuk membawa pelaku, penyelenggara, penyandang dana dan sponsor dari serangan teroris ke pengadilan, anggota Dewan menegaskan kembali bahwa terorisme dalam segala bentuk merupakan salah satu ancaman paling serius terhadap perdamaian dan keamanan internasional, dan bahwa setiap tindakan terorisme adalah kriminal dan tidak bisa dibenarkan.

Dalam pernyataan pers mereka, para anggota Dewan juga menekankan prinsip mendasar dari tidak dapat diganggu gugat agen diplomatik dan petugas konsuler dan kewajiban, termasuk di bawah Konvensi Wina 1961 tentang Hubungan Diplomatik dan Konvensi Wina tahun 1963 tentang Hubungan Konsuler, untuk mengambil semua langkah-langkah yang sesuai untuk mencegah serangan terhadap agen diplomatik dan petugas konsuler.

Berikut adalah perkembangan kasus setelah Turki dan Rusia sepakat untuk melakukan investigasi bersama, dikutip dari situs web Aljazeera: ${ }^{7)}$

\footnotetext{
7) Anonim, "Turkey implicates Gulen in 2016 Andrei Karlov murder", https://www.aljazeera.com/news/2018/04/turkey-orders-arrest-fethullah-gulen-russian-envoy-murder180402151420012.html, diakses pada 18 Juni 2018.
} 
Pengadilan Turki telah memerintahkan penangkapan pemimpin agama Islam yang berbasis di AS, Fethullah Gulen dan tujuh orang lainnya atas pembunuhan Duta Besar Rusia di Turki pada tahun 2016, menurut laporan media pemerintah sehubungan dengan pembunuhan itu. Pihak berwenang sejauh ini telah menangkap tujuh orang lainnya, termasuk tiga polisi, surat kabar Hurriyet melaporkan. ${ }^{8)}$

- Pengumuman dilakukan sehari sebelum Presiden Rusia Vladimir Putin tiba di Turki pada kunjungan resmi. Andrei Karlov, diplomat Rusia, ditembak oleh polisi yang tidak bertugas ketika berada di pameran di Ankara pada bulan Desember 2016.

Si penyerang berteriak "Allahu Akbar" dan "Jangan lupakan Aleppo!" saat ia melepaskan tembakan, tampaknya mengacu pada keterlibatan Rusia di negara tetangga, Suriah. Dia ditembak mati oleh polisi di tempat kejadian. Putin tiba pada kunjungan dua hari pada hari Selasa dan akan bertemu Presiden Recep Tayyip Erdogan dan Presiden Iran Hassan Rouhani.Tiga negara tersebut adalah penjamin dari pembicaraan damai Astana yang telah mengatur zona "deeskalasi" di Suriah yang dilanda perang.

Erdogan mengatakan kelompok Gulen berada di belakang pembunuhan itu, tuduhan diutarakan terhadap pemimpin agama, yang juga seorang pengusaha, telah membantah. Turki juga menuduh Gulen dan para pendukungnya mendalangi upaya kudeta yang gagal musim panas lalu yang menewaskan sekitar 300 orang dan menyebabkan penangkapan di seluruh negeri. Gulen, yang hidup dalam pengasingan di AS sejak 1999, membantah tuduhan itu dan mengutuk upaya kudeta.

Menurut sumber peradilan, pengadilan mengeluarkan surat perintah penangkapan yang menghubungkan pembunuh Karlov, Mert Altintas, ke Gulen.

\footnotetext{
${ }^{8)}$ Anonim, "Turkey orders arrest of cleric Gulen over killing of Russian envoy", https://www.reuters.com/article/us-turkey-security-russia/turkey-orders-arrest-of-cleric-gulen-overkilling-of-russian-envoy-idUSKCN1H90V5, diakses pada 18 Juni 2018.
} 
Alasan dari penerbitan surat perintah tersebut dikarenakan terdapat kejahatan pembunuhan berencana dan upaya untuk menggulingkan tatanan konstitusional. Bukti dan pernyataan saksi memungkinkan biro investigasi untuk mencurigai anggota FETO di markas keamanan, kata Anadolu.

Altintas berasal dari Soke di Turki barat daya, dianggap sebagai salah satu wilayah paling sekuler di negara itu. Ayahnya mengatakan perilaku putranya mulai berubah setelah ia bergabung dengan akademi polisi, di mana ia menjadi lebih saleh, menurut laporan media pada saat itu.

Berikut adalah perkembangan kasus terkait salah satu tersangka yang belum berhasil ditangkap tersangka dari situs Hurriyet Daily News $:^{9)}$

Amerika Serikat sedang menunggu bukti dari Turki terkait ulah Fethullah Gülen terkait dengan pembunuhan 2016 Duta Besar Rusia untuk Ankara Andrei Karlov, dan akan mempertimbangkan permintaan ekstradisi yang sesuai, kata juru bicara Departemen Kehakiman Nicole Navas Oxman. "Kami akan meninjau semua materi yang mungkin diberikan pemerintah Turki dalam hal ini dan akan membuat keputusan tentang ekstradisi atas dasar atau fakta dan undang-undang AS yang relevan," kata Oxman kepada kantor berita Rusia, Tass, pada 2 April.

\section{B. Analisis Terhadap Tewasnya Duta Besar Rusia}

Analisis terhadap tewasnya Duta Besar Rusia menggunakan aturan-aturan dalam Konvensi Wina. Konvensi adalah suatu istilah yang dipakai untuk menyebutkan suatu perjanjian internasional multilateral. ${ }^{10)}$ Perjanjian tersebut tidak dapat dipaksakan terhadap negara-negara. Negara-negara yang belum menjadi peserta konvensi dapat menjadi peserta konvensi melalui ratifikasi,

9) Anonim, “US 'awaiting evidence' from Turkey over Gülen's links to murder of Russian envoy Karlov” ,http://www.hurriyetdailynews.com/us-to-consider-extraditing-gulen-over-murder-ofrussian-envoy-karlov-justice-department-spokesperson-129689, diakses pada 18 Juni 2018.

${ }^{10)}$ I Wayan Parthiana, Hukum Perjanjian Internasional, (Bandung: Mandar Maju, 2002), hal.28. 
aksesi atau suksesi. Namun setelah negara sudah menjadi peserta dari konvensi, maka negara tersebut terikat dengan konvensi tersebut.

Syarat untuk menjadi peserta dalam konvensi adalah negara. Negara adalah subjek hukum internasional dalam arti yang klasik, dan telah demikian halnya sejak lahirnya hukum internasional. Bahkan hingga sekarang masih ada anggapan bahwa hukum internasional itu pada hakekatnya adalah hukum antar negara. ${ }^{11)}$

Konvensi Wina 1961 tentang Perwakilan Diplomatik memberi kemudahan bagi para pejabat diplomatik dalam melaksanakan fungsi misi diplomatik, kemudahan tersebut berupa hak-hak untuk menikmati kekebalan dan keistimewaan diplomatik. Kekebalan dan keistimewaan diplomatik yang disebutkan di dalam konvensi Wina 1961 menurut pelaksanaanya dapat dibagi dalam empat kategori yaitu: ${ }^{12}$

1. Ratione personae, yang menyangkut orang-orangnya;

2. Ratione materiae, yang berkaitan dengan kepemilikan perwakilan diplomatik dan staf diplomatik;

3. Ratione temporae, lamanya kekebalan dan keistimewaan yang dinikmati;

4. Ratione loci, yang diberikan menurut tempatnya.

Ratione Personae, para pejabat termasuk keluarganya yang merupakan bagian dari rumah tangganya tidak boleh diganggugugat. Ia tidak boleh ditangkap dan dikenakan penahanan. Negara penerima harus mengambil langkah-langkah yang layak untuk mencegah setiap serangan atas diri, kebebasan dan martabatnya. Para pejabat diplomatik juga kebal dari kekuasaan hukum pidana negara penerima termasuk kebal dari kekuasaan hukum pedata dan acara. Ratione Personae adalah kekebalan dan keistimewaan terhadap orang. ${ }^{13)}$

Ratione materiae, negara penerima sesuai dengan peraturan perundangundanganya yang berlaku mengizinkan pemasukan dan memberikan pembebasan dari semua bea masuk, pajak dan lain-lain, biaya untuk keperluan resmi perwakilan diplomatik dan barang-barang untuk keperluan pribadi dari seorang pejabat diplomatik dan anggota keluarganya yang merupakan bagian dari rumah tangganya termasuk barang-barang yang dimaksudkan untuk kedudukanya. Ratione materiae adalah kekebalan dan keistimewaan terhadap obejk berupa bead an pajak. ${ }^{14}$

11)) T. May Rudy, Hukum Internasional ,(Bandung: Refika Aditama, 2006), hal. hal 2.

12) Sumaryo, Op. Cit., hal 137.

${ }^{13)}$ Sumaryo, Loc. Cit., hal 137

${ }^{14)}$ Sumaryo, Loc. Cit., hal 137. 
Ratione Temporis, para pejabat diplomatik dapat menikmati kekebalan dan keistimewaan seak mereka memasuki wilayah negara penerima dalam perjalanan untuk menunaikan tugasnya atau bila sudah berada diwilayah itu sejak saat pengangkatanya diberitahukan kepada kementrian luar negeri negara penerima. Sebaliknya kekebalan dan keistimewan itu berakhir takkala tugas mereka berakhir, meninggalkan negara penerima atau pada waktunya habis satu masa yang layak utuk itu tetapi harus tetap berlaku sampai waktu berangkat bahkan dalam keadaan sengketa. Namun mengenai tindakan-tindakan yang dilakukan oleh mereka tersebut dalam rangka melaksanakan tugasnya sebagai anggota perwakilan diplomatik kekebalan itu tetap berlaku. Ratione temporis adalah awal dan berakhirnya kekebalan dan keistimewaan diplomatik. ${ }^{15)}$

Ratione Loci, kekebalan dan keistimewaan diberikan oleh para diplomat di seluruh wilayah akreditasi di negara penerima dan diwilayah negara ketiga yang telah memberikan visa apabila visa itu diperlukan dalam perjalanan menuju ke atau kembali ke tempat penugasan ataupun kembali kenegaranya sendiri. Kekebalan dan keistimewaan semacam itu juga diberikan kepada keluarga mereka baik yang berpergian sendiri untuk bergabung maupun dalam menyertai pejabat diplomatik tersebut. Ratione loci adalah tempat berlakunya keistimewaan dan kekebalan diplomatik. ${ }^{16)}$

Kekebalan diplomatik dalam konvensi wina di nikmati oleh perwakilan diplomatik termasuk kepala perwakilan dan staff perwakilan diplomatik. Pemberian hak kekebalan dan keistimewaan bagi perwakilan asing disuatu negara pada dasarnya bukanlah untuk kepentingan individu, tetapi untuk menjamin pelaksanaan tugas dan fungsi perwakilan di negara penerima sehingga perwakilan diplomatik dapat melaksanakan tugasnya dengan baik. Keistimewaan dan kekebalan diplomatik diharapakan mempermudah pelaksanaan fungsi dari pejabat diplomatik. ${ }^{17)}$

Terdapat beberapa teori yang terkait dengan pemberian kekebalan dan

keistimewaan diplomatik, antara lain : ${ }^{18)}$

1. Teori Exterritoriality

Dasar teori ini adalah Exterritorialiteit. Artinya ialah bahwa seseorang wakil diplomatik itu karena Exterritorialiteit dianggap tidak berada di wilayah negara penerima, tetapi berada di wilayah negara pengirim,

${ }^{15)}$ Sumaryo, Loc. Cit., hal 137.

16) Ibid., hal 138.

${ }^{17)}$ Kadek Anggisita Mahadewi, Penyalahgunaan Hak Kekebalan dan Keistimewaan Oleh Pejabat Diplomatik Arab Saudi terhadap Pelayan Pribadinya di Jerman, (Yogyakarta: FH Atma Jaya,2017), hal. 5.

18) Edy Suryono dan Moenir Arisoendha, Hukum Diplomatik Kekebalan dan Keistimewaanya. (Bandung: Angkasa, 1991). Hal 31. 
meskipun kenyataanya di wilayah negara penerima. Oleh karena itu maka dengan sendirinya seorang wakil diplomatik itu tidak takluk kepada hukum negara penerima. Begitu pula ia tidak dapat dikuasai oleh hukum negara penerima dan tidak takluk pada segala peraturan negara penerima

2. Teori Representative Character

Teori ini mendasarkan pemberian kekebalan-kekebalan diplomatk dan hak-hak istimewa kepada sifat perwakilan dari seorang diplomat, yaitu karena ia mewakili kepala negara atau negaranya diluar negeri.

3. Teori Funtional Necessity

Menurut teori ini, dasar kekebalan-kekebalan dan hak-hak istmewa seorang wakil diplomatik adalah bahwa seorang wakil diplomatik harus dan perlu diberi kesempatan seluas-luasnya untuk melakukan tugasnya dengan sempurna. Segala yang mempengaruhi secara buruk haruslah di cegah.

Fungsi misi diplomatik tertuang dalam Pasal 3 Konvensi Wina 1961 diantaranya adalah:

Ayat 1 :

a) untuk mewakili Negara pengirim di negara Penerima;

b) melindungi kepentingan Negara pengirimnya dan kepentingan warga negaranya di Negara penerima dalam batas-batas yang diperbolehkan oleh hukum internasional;

c) melakukan negosiasi dengan Pemerintah Negara penerima;

d) memperoleh kepastian dengan semua cara yang sah tentang keadaan dan perkembangan di Negara penerima dan melaporkannya kepada Pemerintah Negara pengirim;

e) meningkatkan hubungan persahabatan antara Negara pengirim dan Negara penerima serta mengembangkan hubungan ekonomi, kebudayaan dan ilmu pengetahuan.

Mulai dan berakhirnya kekebalan dan keistimewan diplomatik diatur dalam Pasal 39, diantaranya adalah:

Ayat 1:

Every person entitled to privileges and immunities shall enjoy them from the moment he enters the territory of the receiving State on proceeding to take up his post or, if already in its territory, from the moment when his appointment is notified to the Ministry for Foreign Affairs or such other ministry as may be agreed.

Ayat 2: 
When the functions of a person enjoying privileges and immunities have come to an end, such privileges and immunities shall normally cease at the moment when he leaves the country, or on expiry of a reasonable period in which to do so, but shall subsist until that time, even in case of armed conflict. However, with respect to acts performed by such a person in the exercise of his functions as a member of the mission, immunity shall continue to subsist.

Kekebalan dan keistimewaan diplomatik tersebut sudah dapat dinikmati sejak saat pejabat diplomatik memasuki wilayah Negara penerima dalam perjalanan untuk memangku jabatannya atau, bila sudah berada diwilayah itu, sejak saat pengangkatannya diberitahukan kepada Kementrian Luar Negeri atau kementrian lain yang disetujui. Kekebalan dan keistimewaan diplomatik tersebut baru akan berakhir sejak perwakilan diplomatik meninggalkan negara penerima.

Salah satu kekebalan diplomatik yang diberikan Konvensi Wina 1961 adalah Personal Inviolability atau tidak boleh digangu-gugatnya pejabat diplomatik, hal tersebut tertuang dalam Pasal 29. Isi Pasal 29 adalah mengenai perihal:

The person of a diplomatic agent shall be inviolable. He shall not be liable to any form of arrest or detention. The receiving State shall treat him with due respect and shall take all appropriate steps to prevent any attack on his person, freedom or dignity.

Pejabat diplomatik harus tidak boleh diganggu-gugat. Ia tidak boleh ditangkap dan dikenakan penahanan. Negara penerima harus memperlakukannya dengan penuh hormat dan harus mengambil langkahlangkah yang layak untuk mencegah serangan atas diri, kemerdekaan dan martabatnya.

Dalam kasus terbunuhnya Duta Besar Rusia, Andrei Karlov. Pada tanggal 19 Desember 2016, Andrei Karlov menghadiri pameran foto yang berjudul Rusia dalam pandangan Turki, pameran tersebut disponsori Kedutaan Rusia. Kunjungannya tersebut dilakukan dalam rangka melaksanakan fungsi diplomatik yang tertuang dalam Pasal 3 Konvensi Wina 1961 diantaranya 
adalah mewakili negara pengirim di negara penerima dan meningkatkan hubungan persahabatan antara negara pengirim dengan negara penerima serta mengembangkan hubungan kebudayaan antar kedua negara.

Turki sebagai negara peserta Konvensi Wina 1961 telah gagal dalam melaksanakan kewajiban yang terkandung dalam Pasal 29, yaitu Negara penerima harus mengambil langkah-langkah yang layak untuk mencegah serangan atas pejabat diplomatik. Hal tersebut dibuktikan dengan kegagalan pemerintah atau aparat keamanan Turki dalam mencegah serangan yang ditujukan terhadap Andrei Karlov saat melaksanakan fungsi diplomatiknya sebagai Duta Besar Rusia. Turki sebagai negara penerima bertanggungjawab atas insiden tersebut.

\section{Tanggung Jawab Turki Berdasarkan Teori Kesalahan}

Terkait dengan pembahasan tentang tanggung jawab negara yang dikaitkan dengan teori kesalahan, maka dalam hukum internasional terdapat dua macam teori tentang kesalahan negara yang membahas tentang apakah tanggung jawab negara terhadap tindakannya yang melanggar hukum atau kelalaianya itu mutlak atau apakah perlu adanya pembuktian kesalahan niat/kehendak dari tindakan pejabat atau agen negara. ${ }^{19)}$ Sehingga tanggung jawab negara dapat dikaitkan dengan teori kesalahan. Terdapat dua teori kesalahan diantaranya adalah :

\section{Teori Objektif}

Menurut teori ini tanggung jawab adalah mutlak. Menurut teori ini manakala suatu pejabat atau agen negara telah melakukan tindakan yang mengakibatkan kerugian terhadap orang lain, maka negaranya bertanggung jawab menurut hukum internasional tanpa dibuktikan apakah tindakan tersebut dilaksanakan dengan maksud baik atau jahat. Dalam teori ini tidak di pertimbangkan unsur suatu perbuatan. ${ }^{20)}$

\footnotetext{
$\left.{ }^{19}\right)$ Huala Adolf, Aspek Aspek Negara Dalam Hukum Internasional ,(Jakarta: RajaGrafindo, 1996) 


\section{Teori Subjektif}

Menurut teori ini tanggung jawab negara ditentukan oleh adanya unsur kesalahan (dolus) atau kelalaian (culpa) pada pejabat atau agen negara yang bersangkutan. $^{21)}$

Turki sebagai peserta Konvensi Wina 1961 dan juga sebagai receiving state bertanggungjawab mutlak atas tewasnya Duta Besar Rusia tanpa harus membuktikan unsur-unsur kesalahan, Karena isi dari pasal 29 menyatakan bahwa pejabat diplomatik tidak boleh diganggu gugat dan mengharuskan receiving state mengambil langkah-langkah yang tepat untuk mencegah serangan yang ditujukan terhadap pejabat diplomatik.

\section{Tanggung Jawab Turki Berdasarkan Draft State Responsibility for Internationally Wrongful Acts 2001}

Pelanggaran yang dilakukan Turki terhadap Konvensi Wina, tepatnya Pasal 29 mengenai tidak diganggugugatnya pejabat diplomatik berakibat pada terjadinya internationally wrongfull act. Dalam Pasal 1, Draft State Responsibility for Internationally Wrongful Acts 2001 dinyatakan bahwa Every internationally wrongful act of a State entails the international responsibility of that State. Maksud dari pasal 1 tersebut adalah setiap internationally wrongful act yang dilakukan suatu negara, menimbulkan tanggung jawab internasional terhadap negara tersebut.

Dalam hukum internasional dikenal adanya dua macam aturan, primary rules dan secondary rules. Primary rules adalah seperangkat aturan yang mendefinisikan hak dan kewajiban negara yang tertuang dalam bentuk traktat, hukum kebiasaan dan instrument lainya. Adapun secondary rules adalah seperangkat aturan yang mendefinisikan bagaimana dan apa akibat hukum apabila primary rules itu dilanggar negara. Secondary rules inilah yang disebut

\footnotetext{
${ }^{20)}$ Huala,. Loc. Cit., hal 187.

${ }^{21)}$ Huala,. Loc. Cit., hal 187.
} 
hukum tanggung jawab negara Sehingga Secondary rules merupakan seperangkat aturan yang menindaklanjuti pelanggaran primary rules. ${ }^{22)}$

Terdapat karakteristik timbulnya tanggung jawab negara seperti halnya $:^{23)}$

1. Adanya suatu kewajiban hukum internasional yang berlaku antara dua negara tertentu;

2. Adanya suatu perbuatan atau kelalaian yang melanggar kewajiban hukum internasional tersebut melahirkan tanggung jawab negara;

3. Adanya kerusakan atau kerugian sebagai akibat adanya tindakan yang melanggar hukum atau kelalaian.

Setiap internationally wrongful acts negara menimbulkan tanggung jawab negara. Tindakan berbuat atau tidak berbuat (omission) dari negara dapat merupakan internationally wrongfull acts yang mengandung dua unsur yaitu dapat dilimpahkan pada negara berdasarkan hukum internasional dan merupakan pelanggaran kewajiban terhadap hukum internasiona. ${ }^{24)}$ Pelanggaran terhadap kewajiban internasional oleh suatu negara menimbulkan tanggung jawab negara.

Unsur-unsur internationally Wrongfull Act tertuang dalam pasal 2 Draft ILC 2001,yaitu:

There is an internationally wrongful act of a State when conduct consisting of an action or omission:

a) Is attributable to the State under international law; and

b) Constitutes a breach of an international obligation of the State.

Maksud dari pasal diatas adalah Internationally Wrongfull Act dapat terjadi apabila terdapat perbuatan atau kelalaian suatu negara yang melanggar kewajiban internasional suatu negara. Sehingga berdasarkan Pasal 1 dan 2 di atas pelanggaran yang dilakukan Turki terhadap Konvensi Wina 1961 menimbulkan tanggung jawab internasional bagi Turki. Kegagalan Turki dalam

${ }^{22)}$ Sefriani, Hukum Internasional Suatu Pengantar, (Jakarta: RajaGrafindo Persada, 2016), hal 254.

\footnotetext{
${ }^{23)}$ Yudha, Loc. Cit,. hal 255.

24) Ibid., hal 256.
} 
mencegah serangan yang ditujukan terhadap Duta Besar Rusia menyebabkan kerugian bagi Rusia sebagai sending states.

Berikut adalah bentuk tanggung jawab internasional yang dapat dilakukan Turki terhadap Rusia berdasarkan Draft ILC 2001:

1. Pasal 30 (Cessation and non-repetition):

The State responsible for the internationally wrongful act is under an obligation:

a) To cease that act, if it is continuing;

b) To offer appropriate assurances and guarantees of non-repetition, if circumstances so require.

Berdasarkan Pasal 30 huruf $\mathrm{b}$, bentuk tanggung jawab yang dapat dilakukan Turki adalah memberikan jaminan terhadap Rusia bahwa pelanggaran terhadap Pasal 29 Konvensi Wina yang menyebabkan tewasnya Duta Besar Rusia tidak terulang kembali. Sehingga dengan pemberian jaminan tersebut memberikan rasa aman bagi Pemerintah Rusia sebagai sending state dan juga rasa aman bagi para perwakilan diplomatik selama bertugas dan melaksanakan fungsi diplomatiknya di Turki. Tentunya pemberian jaminan tersebut harus dibuktikan dengan tindakan Turki di masa yang mendatang yaitu berupa tindakan peningkatan keamanan bagi para perwakilan-perwakilan diplomatik yang sedang melaksanakan fungsi diplomatic di Turki.

2. Pasal 31 (Reparation):

1) The responsible State is under an obligation to make full reparation for the injury caused by the internationally wrongful act.

2) Injury includes any damage, whether material or moral, caused by the internationally wrongful act of a State.

Berdasarkan Pasal 31, Turki wajib memberikan reparasi penuh terhadap kerugian moral yang dialami Rusia. Reparasi dalam kasus ini tentunya bukan 
reparasi dalam bentuk materi karena tidak terdapat kerugian materiil. Sehingga reparasi tersebut harus sesuai dengan kejadian yang dialami.

3. Pasal 34 ( Forms of Reparation):

Full reparation for the injury caused by the internationally wrongful act shall take the form of restitution, compensation and satisfaction, either singly or in combination, in accordance with the provisions of this chapter.

Reparasi Penuh yang dimaksud dalam pasal 31 terdiri dari restitution, compensation dan satisfaction. Bentuk reparasi yang dapat dilakukan oleh Turki adalah satisfaction, karena Rusia tidak mengalami kerugian materiil. Dalam kasus ini reparasi penuh berupa restitusi tidak dapat dilakukan karena kerugian yang dialami Rusia bukan bersifat sesuatu yang dapat dikembalikan ke keadaan semula. Reparasi penuh berupa kompensasi juga tidak dapat dilakukan Turki, karena Rusia tidak mengalami kerugian materiil. Kerugian bagi pihak Rusia alam kasus ini tidak dapat diperhitungkan secara materiil, mengingat dalam kasus ini adalah Rusia kehilangan Duta Besar senior miliknya.

4. Pasal 37 (Satisfaction):

1) The State responsible for an internationally wrongful act is under an obligation to give satisfaction for the injury caused by that act insofar as it cannot be made good by restitution or compensation.

2) Satisfaction may consist in an acknowledgement of the breach, an expression of regret, a formal apology or another appropriate modality.

3) Satisfaction shall not be out of proportion to the injury and may not take a form humiliating to the responsible State

Satisfaction adalah pengakuan atas pelanggaran, ekspresi penyesalan, permintaan maaf resmi, atau cara lain yang sesuai. Dalam kasus ini Reparasi yang hanya dapat dilakukan oleh Rusia adalah satisfaction, mengingat Rusia dalam insiden ini tidak mengalami kerugian materi. Kerugian yang dialami Rusia adalah kehilangan Duta Besar Senior miliknya. Sehingga reparasi berupa satisfaction merupakan satu-satunya bentuk reparasi yang dapat 
dilakukan oleh Turki terhadap Rusia. Turki dalam kasus ini dapat melakukan permohonan maaf secara resmi terhadap Rusia atas kegagalanya menjalankan isi Pasal 29 Konvensi Wina 1961 tentang inviolability seorang perwakilan diplomatik. Selain permintaan maaf secara resmi, Turki juga dapat menyatakan ekspresi penyesalan terhadap Rusia, atas kegagalannya dalam mencegah serangan yang ditujukan terhadap Andrei Karlov, Duta Besar Rusia.

\section{E. Kewajiban Turki Berdasarkan Konvensi New York 1973 tentang Pencegahan Dan Penghukuman Kejahatan Terhadap Orang-orang Yang Menurut Hukum Internasional Dilindungi Termasuk Para Diplomat.}

Duta Besar sebagai perwakilan suatu negara merupakan internationally protected person. Hal tersebut tertuang dalam Pasal 1:

Any representative or official of a State or any official or other agent of an international organization of an intergovernmental character who, at the time when and in the place where a crime against him, his official premises, his private accommodation or his means of transport is committed, is entitled pursuant to international law to special protection from any attack on his person, freedom or dignity, as well as members of his family forming part of his household.

Sehingga Duta Besar Rusia sebagai internationally protected person harus dilindungi dari berbagai gangguan yang dapat mengancam keselamatannya. Berhubung dengan kasus tewasnya Duta Besar Rusia,berikut adalah bebrapa bentuk kewajiban Turki terkait dengan tindak kejahatan terhadap internationally protected person yang terjadi di wilayahnya berdasarkan Konvensi New York 1973:

1. Pasal 2:

1) The intentional commission of:

a) A murder, kidnapping or other attack upon the person or liberty of an internationally protected person;

b) An act constituting participation as an accomplice in any such attack shall be made by each State Party a crime under its internal law. 
2) Each State Party shall make these crimes punishable by appropriate penalties which take into account their grave nature.

Dapat di ketahui dalam Pasal 2 ayat 1 dan 2 bahwa pelaku yang diduga berpartisipasi dalam kejahatan yang menyebabkan tewasnya Duta Besar Rusia harus dihukum dengan hukuman yang sesuai dengan tindakannya. Turki sebagai peserta dari konvensi ini harus menghukum pelaku tersebut. Dalam perkembangannya Turki sedang berusaha melaksanakan kewajiban tersebut, hal ini dibuktikan dengan perintah penangkapan oleh pengadilan Turki terhadap Fethullah Gulen dan 7 orang pengikut Gulen yang diduga terlibat dalam rencana pembunuhan Duta Besar Rusia.

\section{Pasal 3:}

1) Each State Party shall take such measures as may be necessary to establish its jurisdiction over the crimes set forth in article 2 in the following cases:

a) When the crime is committed in the territory of that State or on board a ship or aircraft registered in that State;

b) When the alleged offender is a national of that State;

c) When the crime is committed against an internationally protected person as defined in article 1 who enjoys his status as such by virtue of functions which he exercises on behalf of that State.

Turki sebagai peserta Konvensi dan negara yang berkepentingan telah menetapkan pelaku-pelaku kejahatan tersebut berada didalam yurisdiksinya. Penerapan Yurisdiksi ini dibuktikan dengan perintah penangkapan yang dikeluarkan pengadilan Turki bagi delapan pelaku diantara pelaku tersebut adalah Fethullah Gulen. Delapan pelaku tersebut diduga berpartisipasi dalam rencana pembunuhan Duta Besar Rusia. Perintah penangkapan tersebut didasarkan dengan bukti-bukti dan saksi di Pengadilan Turki. Kemudian Turki melakukan permohonan ekstradisi kepada Amerika Serikat, agar Fethullah Gulen dapat diadili di Turki. Mengingat Fethullah Gulen tidak berada di wilayah Turki dan sedang menetap di Amerika Serikat dengan status tidak memiliki kewarganegaraan. 


\section{Pasal 6:}

1) Upon being satisfied that the circumstances so warrant, the State Party in whose territory the alleged offender is present shall take the appropriate measures under its internal law so as to ensure his presence for the purpose of prosecution or extradition. Such measures shall be notified without delay directly or through the Secretary-General of the United Nations to:

a) The State where the crime was committed;

b) The State or States of which the alleged offender is a national or, if he is a stateless person, in whose territory he permanently resides;

c) The State or States of which the internationally protected person concerned is a national or on whose behalf he was exercising his functions;

d) All other States concerned; and

e) The international organization of which the internationally protected person concerned is an official or an agent.

Dalam Pasal 6 ayat 1 huruf a memberi kesempatan bagi negara dimana pelaku kejahatan tersebut berada untuk melakukan langkah-langkah berupa ekstradisi ataupun penuntutan bagi pelaku kejahatan, Langkah-langkah tersebut harus diberitahukan terhadap negara dimana tindakan kejahatan tersebut dilakukan. Dalam perkembangan kasus, Amerika memberikan respon terhadap ekstradisi yang diajukan Turki atas Fethullah Gulen. Amerika Serikat akan mengabulkan ekstradisi apabila bukti dan materi tekait kejahatan Fethullah Gulen yang diajukan oleh Turki terhadap Amerika sudah cukup, Hingga saat ini Amerika Serikat belum mengabulkan ekstradisi tersebut. Turki masih dalam proses memenuhi permintaan Amerika dalam mengumpulkan bukti.

4. Pasal 10:

1) States Parties shall afford one another the greatest measure of assistance in connection with criminal proceedings brought in respect of the crimes set forth in article 2, including the supply of all evidence at their disposal necessary for the proceedings. 
Dalam Pasal 10 ayat 1 mengatur mengenai negara yang terlibat diwajibkan membantu proses penuntutan, termasuk memberikan bukti-bukti untuk proses penuntutan. Pengumpulan bukti sudah dilakukan secara aktif oleh Turki dalam persidangan dan investigasi bersama Rusia. Dalam investigasi bersama, Rusia dan Turki berusaha untuk membuka isi hard disk laptop dan smartphone milik Mevlut Mert Altintas, pelaku dalam penembakan Duta Besar Rusia.

\section{PENUTUP}

\section{A. Kesimpulan}

Turki sebagai peserta dari Konvensi Wina 1961 dan juga sebagai receiving state memiliki kewajiban untuk melaksanakan isi dari Pasal 29 bahwa Negara penerima harus memperlakukannya dengan penuh hormat dan harus mengambil langkah-langkah yang layak untuk mencegah serangan atas diri, kemerdekaan dan martabatnya. Turki gagal dalam melaksanakan isi Pasal 29 Bentuk Tanggung Jawab Turki

Turki bertanggungjawab secara mutlak dalam kejadian tersebut. Bentuk tanggung jawab yang dapat di berikan Turki Berdasarkan Draft ILC 2001 adalah non-repetition dan satisfaction. Non-repetition dalam kasus ini adalah pemberian jaminan oleh Turki terhadap Rusia bahwa pelanggaran terhadap Pasal 29 Konvensi Wina tidak akan terulang kembali, hal tersebut juga dengan upaya Turki dalam memperketat keamanan bagi perwakilan yang bertugas di wilayah teritorialnya. sedangkan Satisfaction yaitu Turki mengakui kesalahannya, mengungkapkan penyesalan dan memberikan permintaan maaf secara resmi terhadap Rusia atas kesalahan yang dilakukan oleh Turki. Dalam perkembangannya Turki dengan itikad baik telah memenuhi kewajibankewajiban yang tertuang dalam Konvensi New York 1973 terkait tewasnya Duta Besar Rusia, hal tersebut terwujud dalam usaha Turki menetapkan yurisdiksi terhadap delapan pelaku yang terlibat dalam rencana pembunuhan Duta Besar Rusia, yang dilanjutkan dengan upaya penangkapan terhadap 
delapan tersangka, tujuh diantaranya telah tertangkap dan satu lagi sedang dalam permohonan ekstradisi karena tersangka tersebut sedang tidak berada di wilayah Turki. Serta upaya Turki dalam mengumpulkan bukti-bukti yang dapat membantu proses penuntutan.

\section{B. Saran}

Turki harus meningkatkan kualitas dari aspek keamanan bagi para perwakilan diplomatik, agar para perwakilan diplomatic dapat melaksanakan fungsinya dengan aman serta agar tidak terjadi insiden serupa yang membahayakan perwakilan diplomatik.

\section{DAFTAR PUSTAKA}

\section{A. Buku}

Adolf, Huala. Aspek Aspek Negara Dalam Hukum Internasional ,Jakarta: RajaGrafindo, 1996.

Ardhiwisastra, Yudha Bhakti. Hukum Internasional Bunga Rampai, Bandung: PT Alumni, 2003.

Edy, Suryono dan Moenir Arisoendha, Hukum Diplomatik Kekebalan dan Keistimewaanya, Bandung: Angkasa, 1986.

Parthiana, I Wayan, Hukum Perjanjian Internasional, Bandung: Mandar Maju, 2002.

Rudy, T May, Hukum Internasional ,Bandung: Refika Aditama, 2006.

Sefriani, Hukum Internasional Suatu Pengantar, Jakarta: Raja Grafindo, 2016.

Suryokusumo, Sumaryo. Hukum Diplomatik Dan Konsuler Jilid I, Jakarta: Tatanusa,2013.

\section{B. Peraturan Perundang-Undangan}

Draft articles of state responsibility for internationally wrongful Acts 2001. 
Konvensi New York 1973 tentang Pencegahan Dan Penghukuman Kejahatan Terhadap Orang-orang Yang Menurut Hukum Internasional Dilindungi Termasuk Para Diplomat.

Konvensi Wina 1961 tentang Perwakilan Diplomatik.

\section{Jurnal}

Anggisita Mahadewi, Kadek. Penyalahgunaan Hak Kekebalan dan

Keistimewaan Oleh Pejabat Diplomatik Arab Saudi terhadap Pelayan

Pribadinya di Jerman. Makalah (Yogyakarta: FH Atma Jaya,17 Januari 2017).

\section{Internet}

Anonim. "Dubes Rusia untuk Turki Tewas Ditembak di Pameran Foto". https://www.voaindonesia.com/a/dubes-rusia-untuk-turki-tewasditembak-di-pameran-foto/3642291.html. Diakses pada 4 Juni 2018.

Anonim. "UN Condemns Assasination of Russian Ambassador to Turkey". https://news.un.org/en/story/2016/12/548152-un-condemns-assassinationrussian-ambassador-turkey. Diakses pada 4 Juni 2018.

Anonim. "Turkey implicates Gulen in 2016 Andrei Karlov murder". https://www.aljazeera.com/news/2018/04/turkey-orders-arrest-fethullahgulen-russian-envoy-murder-180402151420012.html. Diakses pada 18 Juni 2018.

Anonim. "Turkey orders arrest of cleric Gulen over killing of Russian envoy". https://www.reuters.com/article/us-turkey-security-russia/turkey-ordersarrest-of-cleric-gulen-over-killing-of-russian-envoy-idUSKCN1H90V5. Diakses pada 18 Juni 2018.

Anonim. 'US ‘awaiting evidence’ from Turkey over Gülen's links to murder of Russian envoy Karlov". http://www.hurriyetdailynews.com/us-toconsider-extraditing-gulen-over-murder-of-russian-envoy-karlovjustice-department-spokesperson-129689. Diakses pada 18 Juni 2018. 
Yonathan Yogy \& Ida Kurnia Tanggung Jawab Negara Terhadap Perlindungan Pejabat Diplomatik Menutur Konvensi Wina 1961 (Contoh Kasus Penyerangan 